\title{
DOMINASI MILITER (ANGKATAN DARAT) DALAM PEMERINTAHAN ORDE BARU
}

\author{
Oleh: \\ Pulung Sumantri
}

\begin{abstract}
ABSTRAK
Di dalam perjalanan historis bangsa Indonesia menempatkan Orde Baru sebagai penguasa terlama dan paling terasa hingga kini. Militer adalah konsep yang menjadi ciri khas dalam pemerintahan Orde Baru. Suharto yang muncul dari organik Angkatan Darat telah mendominasi pemerintahan yang juga berasal dari Angkatan Darat pada umumnya. Meskipun terdapat unsur-unsur militer lainnya, Angkatan Darat-lah yang paling nyata berkuasa selama 32 tahun pemerintahan Orde Baru. Melalui kajian literatur, tulisan ini akan mengupas tonggaktonggak kekuasaan Angkatan Darat dalam kekuatan militer yang berkuasa besar di tiap lini pemerintahan. Hasil yang didapat adalah perubahan-perubahan dalam realitas historis bangsa Indonesia yang militernya berganti-ganti berkuasa dalam pemerintahan. Mulai dari Angkatan Laut di masa kerajaan-kerajaan Jawa (Singashari, Majapahit dan Mataram) dan Sumatera (Sriwijaya dan Aceh) hingga kemerdekaan yang menempatkan Angkatan Darat sebagai pemenang dalam kekuasaan. Dominasinya di dalam pemerintahan sangat terasa selama 32 tahun Orde Baru memerintah.
\end{abstract}

Kata Kunci: Militer, Angkatan Darat, Pemerintahan, Orde Baru. 


\section{PENDAhuluan}

Tidak dapat dipungkiri, ketika berbicara Orde Baru, maka yang terbayang adalah militerisme. Pemerintahan Indonesia pada masa itu dipegang militer. Segala posisi puncak dalam birokrasi negara, baik legislatif maupun eksekutif, didominasi oleh militer. Formal-informal, legal-ilegal, militer ikut andil didalamnya. Untuk yang ilegal atau informal mungkin sulit untuk dilihat bagaimana peran militer didalamnya, namun sangat gampang untuk dirasakan. Berdasarkan sebuah sumber, peran militer dalam pada masa Orde Baru menempati jabatan-jabatan politis yang strategis menjalankan roda pemerintahan negara, seperti menteri, gubernur, bupati, anggota Golkar dan duduk mewakilinya dirinya di DPR.

Pada tahun 1966, anggota militer yang menjadi menteri sebanyak 12 orang dari 27 anggota kabinet dan 11 anggota militer yang menempati jabatan strategis di departemen-departemen urusan sipil. Di DPR, sebanyak 75 anggota militer duduk mewakili militer. Di tingkat daerah, pada tahun 1968, sebanyak 68\% gubernur dijabat oleh anggota militer, dan $92 \%$ pada tahun 1970. Sementara, pada tahun 1968, terdapat sebanyak 59\% bupati di Indonesia berasal dari anggota militer. Kemudian pada tahun 1973, jumlah militer yang menjadi menteri sebanyak 13 orang; sebanyak 400 anggota militer dikaryakan di tingkat pusat, dan 22 dari 27 gubernur di Indonesia dijabat oleh militer.

Tahun 1982, sebanyak 89\% jabatan-jabatan strategis di tingkat pusat yang berkaitan dengan persoalan sipil dijabat oleh anggota militer. Kemudian pasca pemilu 1987, sebanyak 80\% anggota DPR dari Fraksi ABRI dan sebanyak 34 perwira senior menjadi anggota DPR melalui Fraksi Golkar. Kemudian, 120 anggota militer terpilih sebagai pimpinan Golkar daerah dan hampir 70\% wakil daerah dalam kongres nasional Golkar berasal di militer. Jumlah fraksi ABRI di DPR juga meningkat dari 75 menjadi 100. Kenaikan ini dianggap tidak layak, karena jumlah ABRI hanya 500.000 orang ( $0,3 \%$ dari jumlah penduduk Indonesia) tetapi mendapatkan kursi $20 \%$ di parlemen. (Cholisin, 2002 dan Pakpahan, 1994) 
Sebuah hal yang menakjubkan bahwa militer telah merasuk kesegala lini birokrasi elit negara. Lebih menakjubkan lagi bahwa peran militer didalamnya mayoritas terdiri atas unsur Angkatan Darat (TNI-AD). Adalah hal yang lumrah jika suatu negara memiliki angkatan perang dengan unsur Darat, Laut dan Udara ditambah organisasi militer dengan tugas pokok keamanan yang dinamakan Polisi, baik sebagai bagian Darat maupun Laut. Pada perkembangannya di masa Orde Baru, Angkatan Daratlah yang paling mendominasi dalam pemerintahan sipil ataupun militer itu sendiri. Namun bukan berarti hal tersebut dimulai pada masa Orde Baru. Ada beberapa alasan historis yang mengantarkan bentuk pemerintahan militeristik seperti itu.

\section{II.PEMBAHASAN}

Pramoedya Ananta Toer (1999) mengatakan bahwa kesalahan pengelolaan militer Indonesia telah lama terjadi sejak Hindia-Belanda. Sebelum menjadi HindiaBelanda, nusantara adalah negara maritim yang besar. Mulai Singosari, Majapahit, bahkan Pada waktu Belanda menguasai Indonesia menjadi kekuasaan maritim di dunia. VOC, Serikat Dagang Belanda yang membangun imperium maritim terbesar di dunia dengan ibukotanya Batavia. Dan Batavia menyebabkan lahirnya Jawasentrisme, semua diukur untuk kepentingan Jawa. Dari Luar Jawa (khususnya daerah Asia Tenggara) membawa harta di bawa ke Jawa. Semuanya Perbuatan VOC. Tetapi kemudian VOC bangkrut, kapal-kapalnya pada tenggelam karena korupsi para pejabat, dengan mengangkuti barang-barang berlebihan. Bangkrut VOC, kemudian muncul pemerintah Hindia-Belanda, karena sudah tidak mempunyai kekuasaan laut lagi. Akhirnya Pertahanan Hindia Belanda itu didasarkan pada pada pertahanan Darat. Padahal untuk negara kepulauan, hal ini melemahkan karena selalu bermasalah dengan integrasi.

Salah satu bukti kelemahan pertahanan Darat untuk negara maritim adalah Pada tahun 1812, waktu Hindia Belanda dikurung oleh Inggris dari laut, dalam beberapa hari angkat tangan. Waktu diserang oleh Jepang pada 1942 dalam beberapa hari juga angkat tangan. Jadi kalau itu diteruskan sampai sekarang, itu bukan lagi kekeliruan, tetapi 
kesalahan. Pertanyaannya adalah apakah Indonesia terlalu banyak belajar dari sejarah atau tidak belajar sama sekali dari sejarah?

Kerajaan-kerajaan di Asia Tenggara memiliki sistem yang berbeda. Sejarawan Barat, Anthony Reid menyebutkan bahwa mengkaji Asia Tenggara adalah satu kesatuan. Berbeda dengan Eropa, walaupun terbagi antara timur-barat, utara selatan, pengkajiannya tetap satu kesatuan. Sedangkan wilayah Asia tidak bisa dikaji sebagai satu kesatuan. Walau India atau Cina dengan peradaban yang terkenal itu, secara geografis dekat dengan Asia Tenggara, tetap belum bisa dikaji sebagai satu kesatuan dengan mereka. Maka pengkajian Asia Tenggra, ditempatkan secara tersendiri terutama historisnya. Ini menandakan daerah Asia Tenggara memiliki sistem yang berbeda.

Sejak kerajaan-kerajaan di Nusantara masih eksis, Jawanisasi telah berkembang dengan baik. Namun terminologi yang digunakan sungguh berbeda setelah Barat mulai menguasai Nusantara hingga Orde Baru, bahkan pada masa Reformasi. Sebelum itu semua, Jawanisasi maksudnya "men-Jawakan" sesuatu yang berasal dari luar ke Jawa. Hubungan dagang hingga ekspansi yang dilakukan hingga abad 16 (sebelum masuknya Barat) dengan kerajaan-kerajaan di wilayah Nusantara lebih bersifat politis. Tidak ada unsur menghilangkan satu sama lain yang berujung pada satu sistem. Yang ada adalah kolaborasi antar sistem yang dianut pada kerajaan-kerajaan di wilayah berbeda sehingga Jawanisasi bukan memusat, namun meluas tanpa menghilangkan sistem yang ada. Ibarat lampu mulai bercahaya, semakin bercahaya dan semakin terang. Ketika Sriwijaya berjaya di Nusantara, yang terjadi dapat dikatakan juga "Sumateranisasi". Inilah apa yang disebut dengan Mancanegara, bahwa batasan wilayah diukur secara politis. Bukan Mancanegara seperti yang di kenal sekarang dengan batasan wilayah.

Ketika Belanda masuk menguasai Nusantara dengan VOC-nya sebagai perusahaan dagang seperti yang telah disebutkan diatas, perubahan telah dimulai. Walaupun dikatakan Pramoedya bahwa semua hasil di Nusantara dibawa ke Jawa, pada prinsipnya demi kepentingan kolonial. Ketika Hindia-Belanda berkuasa kepentingan ini menjadi semakin sentralistik. Yang dikirim keluar pulau Jawa bukan lagi demi 
kepentingan politis tetapi penaklukan-penaklukan demi menguasai perdagangan. Yang digunakan adalah orang Jawa sebagai pekerja dan militer (pasukan Mangkunegaran) demi kepentingan Belanda. Semuanya dilakukan dengan terpusat pada Batavia. Ini yang mula-mula memperkecil kekuatan politis Jawa hanya sebagai satu kekuatan wilayah.

Indonesia telah benar-benar menjadi kekuasaan yang terpusat di Pulau Jawa pada saat Jepang berkuasa 1942. Aksi fasisme Jepang lebih dikonsentrasikan pada kekuatan Angkatan Darat yang banyak di isi oleh orang-orang Indonesia seperti Heiho, GyuGun, Tokubetsu Keisatsutai, Tokubetsu Hikojo Kinmutai, dan badan semi militer seperti Mokutai, Kenkotai Sintai, Keibodan, Seinenda Yang hampir semuanya berada di Jawa.

Di luar Jawa, angkatan-angkatan militer tidak lebih besar karena konsentrasi kekuasaan Jepang lebih kepada ekspolitasi sumber daya alam. Walaupun begitu kekuatannya lebih besar dari masa pendudukan Belanda. Tokoh-tokoh militernya pun lebih dikenal berasal dari Angkatan Darat seperti Soedirman, Urip Sumoharjo, A.H. Nasution, T.B. Simatupang. Angkatan Laut dan Angkatan Udara hanya beberapa dan tidak dikenal dalam historiografi Indonesia karena memang lebih dipersiapkan menggunakan senjata yang lebih gampang dipakai dan gampang dicari di daratan karena menurut negri jajahan orang Indonesia mayoritas dapat menggunakan senjata sederhana yang gampang dipelajari. Apalagi tingkat buta huruf yang besar ketika Jepang mensurvei orang Indonesia pada saat pendudukannya.

Kelihatan ketika pembentukan militer di awal-awal kemerdekaan, bahwa BKR (Badan Keamanan Rakyat) dan TKR (Tentara Keamanan Rakyat) bermula dari Jawa. Sedangkan di daerah-daerah masih berbentuk laskar rakyat. Ketika penggabungan laskar-laskar rakyat di daerah menjadi satu komando di bawah organisasi militer formal, praktis bahwa Angkatan Darat sudah mulai mendominasi terutama perubahan BKR yang pada saat dibentuk berada di bawah koordinasi sipil, berubah menjadi TKR sebagai lembaga otonom ketentaraan (Purwanto, 2006: 211). 
Kekuatan militer mulai mendapat posisi penting ketika terjadi serangkaian pemberontakan-pemberontakan di daerah dimana Soekarno sangat membutuhkan militer untuk meredam pemberontakan yang terjadi. Semenjak itu, posisi militer semakin kuat di arena-arena politik. Apalagi ketika A.H. Nasution mencetuskan konsep Dwi-Fungsi TNI pada ulang tahun Akademi Militer Nasional (AMN) tanggal 12 November 1958 di Magelang yang menyebut dua peran militer yaitu fungsi militer dan "fungsi wilayah" atau pembina masyarakat. Inilah yang menurut Nasution merupakan kekuatan sosial, kekuatan rakyat yang bahu-membahu dengan kekuatan rakyat lainnya. Angkatan Darat semakin kuat di arena politik. Bukan saja karena Nasution berasal dari Angkatan Darat, penumpasan-penumpasan gerakan spratis didaerah banyak dilakukan atas jasa Angkatan Darat.

Melihat peran militer semakin kuat dalam perpolitikan negara, Soekarno mulai membatasi gerak militer dengan cara mengganti Nasution sebagai KSAD kepada Ahmad Yani pada Juni 1962 yang mencabut Undang-undang Keadaan Bahaya (SOB). Tidak itu saja, setelah dikeluarkannya dekrit presiden yang mengubah sistem pemerintahan menjadi demokrasi terpimpin, mengantarkan Soekarno menjadi panglima tertinggi angkatan bersenjata. Tampak sejak 1956 hingga akhir kekuasaannya, atribut militer yang dikenakannya semakin "memberatkan" bajunya. Sampai disini historiografi mencatat persaingan politik dalam tiga kubu yaitu Soekarno, PKI, dan Angkatan Darat. Pecahnya peristiwa G-30-S 1965, mengantarkan Angkatan Darat sebagai pemenang dalam kekuasaan Indonesia yang mengantarkan Soeharto menjadi presiden RI kedua.

\section{PENUTUP}

Mulai 1966, setelah Pemilu dimenangkan, praktis angkatan darat berkuasa ketika Soeharto menjadi presiden yang berasal dari Angkatan Darat. Sebagai militer, Soeharto berpikiran seperti militer. Segala sesuatunya tentang militer didapatkan dari didikan Jepang di PETA. Dalam aertikel R.E. Elson disebutkan bahwa ia mempelajari solidaritas grup, pentingnya disiplin, aturan yang terkontrol, kepentingan hirarki dan 
arti tugas. Ditambahkan juga bahwa tidak pernah ragu untuk bertindak. Semua ini di realisasikan dalam mengelola Indonesia di Orde Baru. Yang paling saya soroti dalam tulisan ini adalah aturan terkontrol, kepentingan hirarki dan ketidakraguan dalam bertindak.

Aturan terkontrol dilakukan dengan sistem pemerintahan yang sentralistik. Kegiatan negara dalam hal apapun selalu harus sampai dalam pemerintahan yang berpusat di Jawa sehingga kontrol dilakukan melalui pusat persis seperti garis komando dalam militer. Hampir sama dengan fasisme Jepang, kegiatan negara, terutama kegiatan ekonomi dilakukan atas kontrol pusat. Berkembanglah Jawanisme yang jauh berbeda jika dibandingkan Jawanisme masa raja-raja Nusantara sebelum kedatangan Barat. Jawanisme lebih dianggap sebagai penjajahan Jawa atas suku-suku lain di Indonesia karena bentuknya bergerak kedalam sehingga kalau di ibaratkan bola lampu, maka "mengubah sinar bola lampu semakin terang kedalam, bukan keluar".

Kepentingan hirarki juga mengubah pola angkatan perang. Kekuasaan terpusat hanya pada kekuatan Angkatan Darat dimana semua angkatan perang digabungkan dalam ABRI (Angkatan Bersenjata Republik Indonesia) dengan panglima besar selalu oleh Angkatan Darat. Ironis dengan bentuk negara kepulauan, malah militer Angkatan Darat yang di perkuat. Hal ini sangat terasa ketika masa reformasi, Angkatan Laut tidak mampu menjaga stabilitas wilayah yang selalu berkaitan dengan masalah integrasi. Belum lagi masalah-masalah perbatasan laut yang tak kunjung usai dengan negara tetangga. Kekuatan angkatan darat dalam struktur negara hanya untuk memuluskan kekuasaan Soeharto yang tidak berimbang dengan kekuatan politik negara. Sedangkan kritik atas keblinger Soeharto dijawab dengan ketidakraguan-nya dalam bertindak. Bukan hanya penjahat, atau preman yang dihabisi, tetapi juga lawan-lawan politik atau bahkan kaum intelektual yang kritis tidak jauh berbeda nasibnya dengan penjahat atau preman. Kemanan yang di ciptakan Soeharto, berbanding lurus dengan ketakutan yang ditimbulkannya.

Walaupun dimasa reformasi, kebebasan lebih terjamin dibandingkan Orde Baru, dan peran militer dalam politik dibatasi, permasalahan-permasalahan dasar dalam 
pemerintahan belum juga dapat terpecahkan. Bangsa ini belum juga dapat melihat sejarah dengan jelas, sehingga jangankan belajar dari sejarah, apa yang terjadi pada masa lalu saja belum sepenuhnya diketahui sehingga apapun yang dilakukan, selalu memiliki pengertian dan tindakan yang salah.

\section{DAFTAR BACAAN}

Fattah, Abdullah. (2005). Demiliterisasi Tentara, Pasang Surut Politik Militer 19452004, Yogyakarta : LKIS.

Hill, David T. (2010). Jurnalisme dan Politik di Indonesia, Jakarta: Yayasan Obor Indonesia.

Kecik, Hario. (2010). Pemikiran Militer 3: Sepanjang Masa Bangsa Indonesia, Jakarta: Yayasan Obor Indonesia.

McGregor, Katherine E.(2008).Ketika Sejarah Berseragam: Membongkar Ideologi Militer Dalam Menyusur Sejarah Indonesia, Yogyakarta: Syarikat.

Nordholt, Henk Schulte; Bambang Purwanto, Ratna Saptari. (2008). Perpektif Baru Penulisan Sejarah Indonesia, Jakarta: Yayasan Obor Indonesia.

Oostindie,Gert, (2016). Serdadu Belanda di Indonesia 1945-1950, Jakarta: Yayasan Obor Indonesia.

Purwanto, Bambang. (2006).Gagalnya Historiografi Indonesiasentris?!, Yogyakarta: Penerbit Ombak.

\section{Arsip}

Pidato Pramoedya Ananta Toer pada peluncuran ulang Media Kerja Budaya, 14 Juli 1999 di Aula Perpustakaan Nasional. 